\title{
Using learning styles in learning objects: a case study in a colombian public university
}

\section{Aplicando estilos de aprendizaje sobre objetos de aprendizaje: un caso de estudio en una universidad pública colombiana}

\author{
Boris Pérez-Gutiérrez ${ }^{1}$
}

Forma de citar: B. Pérez, "Using learning styles in learning objects: a case Study in a Colombian Public University", Respuestas, vol. 19, no. 2, pp. 59-69, 2014.

Recibido:

Febrero 10 de 2014

Aceptado:

Abril 22 de 2014
${ }^{1}$ Magister en Ingeniería de

Sistemas y Computación

borisperezg@ufps.edu.co

Universidad Francisco de Paula

Santander

Cúcuta, Colombia

\section{Abstract}

Background: computer-programming courses aren't easy to study. Some authors have studied the difficulties in learning programming to support developing learning materials for basic programming courses. In Colombia there is an approach to teaching programming using an active learning approach (Interactive Learning Objects - ILOs) as one of the components that reinforce their pedagogical model, by supporting the generation of high-level programming skills. Objective: we want to explore the possibilities of using Learning Styles and Team Learning to increase the learning levels of Computer Programming students. Methods: this study was applied outside of the classroom in order to encourage autonomous learning. To do this we'll pick a sample and apply a series of comparative tests between research groups. Results: the objective was met by effectively showing that providing content based LS and team-based leaning can improve a student's performance. The intervention group grades were better than those of the comparison group though they should be analyzed further to get a more accurate conclusion. Conclusion: This study will give us the chance to see whether the strategy can be applied to the Francisco de Paula Santander University students.

Keywords: Active learning, informal learning, learning objects, learning styles, team-based learning

\section{Resumen}

Antecedentes: la programación de computadores es un tema difícil de aprender. Algunos autores han estudiado las dificultades en el aprendizaje de la programación para soportar el desarrollo de materiales de aprendizaje para los cursos básicos de programación. En Colombia hay un enfoque para enseñar programación usando aprendizaje activo (Objetos Interactivos de Aprendizaje) como uno de los componentes que refuerzan el modelo pedagógico, al apoyar la generación de habilidades de 
programación de alto nivel. Objetivo: se busca explorar las posibilidades al utilizar Estilos de Aprendizaje y Aprendizaje en Equipo para mejorar en los estudiantes los niveles de aprendizaje de programación. Métodos: este estudio se aplicó fuera del salón de clase para fomentar el aprendizaje autónomo. Para esto se seleccionó una muestra y se aplicaron una serie de pruebas comparativas entre los grupos de investigación. Resultados: el objetivo se cumplió al mostrar que efectivamente que esta estrategia puede mejorar el desempeño de un estudiante. Las calificaciones del grupo de intervención fueron mejores que las del grupo de comparación, sin embargo, estos resultados deben analizarse a profundidad para obtener una conclusión para exacta. Conclusión: este estudio nos dará la oportunidad de revisar si esta estrategia puede aplicarse a los estudiantes de la Universidad Francisco de Paula Santander.

Palabras clave: Aprendizaje activo, aprendizaje basado en equipos, aprendizaje informal, estilos de aprendizaje, objetos de aprendizaje.

\section{Introduction}

The Francisco de Paula Santander University (UFPS) is a public higher education institution located on the Colombia-Venezuela border in the state of Norte de Santander. The UFPS is an affordable institution so that is why it is so attractive for students from low-income backgrounds whom wouldn't otherwise have the chance to study post-secondary school.

Every semester around 200 applications are received although only 60 are accepted as students into the Computer Science program [1].

According to a survey conducted online, some of these students come from schools without computer labs, so students had no opportunity to get close to such technology. Other students come from schools where they have had the chance to learn the basic concept of computer programming, and others have taken courses on programming techniques.

The Departamento Administrativo Nacional de Estadística - DANE [2] has statistics regarding the penetration of technology at home, showing that only $33 \%$ of homes in the central region of the country have computers, and only $26.1 \%$ have internet access. These numbers are even slower in our town.

Students' knowledge of computers and the Internet is orientated towards social networks. Also, our students have no knowledge of the English language [3]. On a national level only $1 \%$ of schools pupils know English.

Another problem the students recognized, thanks to an online survey, is that they only dedicate study time to classes rather than complementing this with other means such as library books or Internet tutorials. The selfstudy mentality just isn't there.

Things get worse for computer-programming courses. These study topics aren't easy to study [4]-[6]. It requires comprehending certain abstract concepts like organizing information in a way it can be understood by the right person; however this isn't always possible 
to teach in a lecture due to the large and heterogeneous groups which make it difficult to design learning material which is beneficial for everyone.

Lahtinen [6] studied the difficulties in learning programming in more than 500 students to support developing learning materials for basic programming courses. Sajaniemi [7] applied a metaphor approach to objectoriented programming by presenting new metaphors for such concepts as class, object, object instantiation, method invocation, parameter passing, object reference, and garbage collection. In Colombia there is an approach to teaching programming using an active learning approach. Villalobos [8] presents an Interactive Learning Objects (ILOs) as one of the components that reinforce their pedagogical model, by supporting the generation of high-level programming skills.

Our problem is because it's difficult to teach students who haven't had sufficient previous contact with technology to program. Many of whom feel pushed away from technology and programming along with it. They don't see it as something they can use to learn by themselves, at their own pace.

But we would be wrong if we put all the blame onto the students, it's also the environment they have grown up in that hasn't allowed them to develop their skills and hence develop their programming abilities.

In addition to this, it becomes difficult for the professor to lecture not only new students but also ones who are repeating the subject as he has to deal with two different paces. If the class is slow, the repeat students lose interest, and if the class moves too fast, the new students feel just as frustrated with not thoroughly understanding what is being taught. This is one of the professors' biggest challenges, achieving the same level of understanding amongst every student. Students confuse some concepts and hence misapply them, and don't worry about misunderstandings until they fail in evaluations. Each of these new students have their own learning abilities, and level of knowledge. Logan and Thomas [9] showed how people exhibit important differences when it comes to problem solving. This makes it especially difficult for a professor who can't teach 30 different ways [10].

Anonline survey filled out last semester showed that students are afraid of asking questions for they feel they lack the knowledge, and don't want to be laughed at. Besides this, the virtual spaces designed for questions are not directly aimed at the topic in question, making it even more difficult for the student to clear up any doubts on the subject, e.g. students cannot highlight specific words or phrases within teaching material in order to query it.

These difficulties cause students frustration, depression and hence demotivation with the course [4], [5], provoking high desertion levels. Within the Computer Science (CS) program we are facing two issues, the heterogeneity of students and the lack of initiative to learn by themselves. In the CS program we think these issues can be handled by creating a better way for the student to get a feel for this knowledge, so we'll focus on two aspects: (a) Applying Learning Styles over Learning Objects (LSiLO) and (b) allowing students to prepare study topics in pairs.

For the first issue we need to realize that each and every student has a unique way of learning, and that a professor cannot teach a class thirty different ways. That's why each LO must be designed following different learning styles. Logan and Thomas [9] showed that individuals with a very visual memory but a weaker one for verbal processing are going to find textual material more difficult to process compared to students with strong verbal abilities. This way a professor can use these LOs to teach a heterogeneous classroom whilst aiming at a multitude of different levelled students, without the need to slow down the pace of others [10].

For the second issue, students make use of LOs with a partner to encourage the checking and discussing of study topics through a collaborative strategy, i.e. team-based
Julio-Diciembre 2014 ISSN 0122-820X

PP: 59-69 
No. 2

Julio-Diciembre 2014 ISSN 0122-820X

PP: 59-69 learning. Using this strategy students will check the study topic, then discuss it, prepare it and finally complete the activities within the LO, giving them the chance to be prepared for class, as well as clearing any doubts they may have.

With the application of these two aspects we look at encouraging not only the learning process of computer programming students and the development of abilities but also an awareness of learning by oneself, allowing them to take initiative in the knowledge appropriation process. This effectiveness begins by recognizing that students are capable of solving problems in different ways. These strategies look to go hand in hand with the traditional classroom learning process.

So, the research question we have to ask is: can learning objects partnered with a team-based learning strategy help encourage autonomous learning among computer programming students?

The organization of the article is as follows. Section 2 contains a concept review. Experimentation and the analysis of the results will be introduced in Section 3. Discussion of results will be shown in Section 4. And conclusions will be presented at the end.

\section{Background}

\subsection{Learning Objects}

In recent years global interest in online learning has been focused on learning objects (LO) [11]. According to Wiley [12] learning objects are 'any digital resource that can be reused to support learning'. This concept, while valid, is quite broad. Polsani's [13] definition has an educational intention: 'A media asset or digital object can become a $\mathrm{LO}$ only when it is incorporated into a form and provides a relation to itself as $\mathrm{LO}$ in order to facilitate the understanding of that object'. Also, Cakiroğlu [11] summarizes that learning objects are defined as discrete chunks of reusable materials or activities that can be brought together with other learning objects to construct learning content. Pukkhem and Vatanawood [14] establishes that learning objects can be educational components presented in any format. Gunawardena and Adamchik [15] defines a LO as an integrated module containing core text, code examples, review questions, supplementary material, and programming labs.

Despite these definitions of LOs, there's still no globally accepted one. So for the purpose of this investigation we decided to use the definition proposed by Cakiroğlu [11], establishing that 'LOs can be united so as to be used in different areas, reused and easily arranged'. This definition would only be improved by saying they are also available online. Meaning students with different learning needs may benefit from LOs, being able to study them at their own pace wherever they may be, autonomously.

A LO looks to provide class material within a course, not an entire course. It also looks to be an instructional aid thanks to its flexibility, accessibility, durability, interoperability and reusability [16]. According to Kaiser [17] LOs do not have any specified size limit because they need to the size of an activity if they are to be used in line with a module or lecture. Examples include simulations, data, tests, surveys and texts and could include adaptable learning modules [14].

Kay [18] analyzed the perception of LOs taking faculty and student perspectives, as well as performance, into account. He identified three obstacles from the point of view of the faculty: (a) Not enough knowledge of LOs to determine their effectiveness, (b) Time required to integrate LOs into the curriculum is too demanding, and (c) Time required to construct good quality LOs would be extensive.

In an academic environment, LOs offer unique capacities especially when within reach of every student so they can work at their own pace, through personalized tutorials along with feedback. With this, the professor can easily work in heterogeneous classes 
facing different levels of understanding [10].

In this day and age, a person's ability to create and consolidate the knowledge required to do so is more important than ever, rather than just accumulating knowledge. This allows the development of skills such as critical thinking, problem solving, decision-making and technological understanding [15].

\subsection{Learning Styles}

Learning Style has a strong influence on the learning process, it is an important criterion for learning personalization [19]. A learning style includes every kind of learning characterized by a single person, such as a concrete way of solving an activity, or strategies used to complete a task.

The concept of learning style suggests everyone is different in respect to how they study more efficiently [19] y [9]. Keefe [20] defines learning style as 'the characteristic cognitive, affective and psychological behaviors that serve as relatively stable indicators of how learners perceive, interact with and respond to learning environments'. We can say that learning styles are reflected on preferences and individual choices and encompass a broad range of factors including that of cognitive styles.

Some researchers have argued that learning style is also a useful indicator for potential learning success on the grounds that it already shares information on individual differences in terms of preferences and information processing [19].

As Griggs [21] points out, learning styles have no relation whatsoever to IQ, mental capacity, or actual learning performance nor can it be said that one style is better than another. The best learning style for an individual is specific to that individual and depends on cognitive capacity and current learning situation of said individual [9].

In this study we used the four learning styles developed by Honey and Mumford [22] based on the work of Kolb [23], those being: Active, Theorist, Pragmatic and Reflector.

Active alumni are enthusiasts of what's new, they tend to act first and think later and get easily bored of long term plans. They look for the: how?

Reflector alumni are more observational, collecting and: analyzing data before coming to a conclusion, looking for the why?

Theorist alumni think step by step, bringing coherent facts together first, they look for the what?

And finally Pragmatic alumni enjoy trying out ideas, theories, new techniques and see if they work in the real world. They look for the what if?

To identify student's particular learning style, Honey and Mumford have developed a Learning Style Questionnaire (LSQ). According to Honey: 'Improve your learning skills and processes. Increased awareness of how you learn, opens up the whole process to self-scrutiny and improvement. Learning to learn is your most important capability since it provides the gateway to everything else you want to develop'. This questionnaire shows a good grade of validity and reliability / internal consistency as well as sharing precise learning style evaluations [14].

\section{Experimentation}

This experiment was developed to evaluate the effectiveness of learning styles in learning objects and a team-based learning strategy, to generate the programming skill set required by students. Most of our students hadn't had proper schooling giving them the ability of self-learning, meaning they don't feel able to learn by themselves nor develop an individual conception of a subject.

At present, 91\% of students who signed up for the 2014-I period come from low income families, and per semester pay the equivalent of around half the Colombian minimum wage,
Julio-Diciembre 2014 ISSN 0122-820X PP: 59-69 
No. 2

Julio-Diciembre 2014 ISSN 0122-820X

PP: 59-69 or about US $\$ 140$.

The design of this project emphasizes the need to listen to students, enabling them to articulate the ways they work with digital materials.

\subsection{Sample}

The study was designed for second semester students taking the Object-Oriented Programming I (POOI) course, which lasts for a whole semester and covers object-oriented programming topics using Java language.

The population surveyed composed of 60 students, using a sample of 30 . Most of these students are taking the course for the first time. The sample was divided into two evenly split groups, one for comparison and the other for intervention (see Table I). The comparison group will get to the subject through an LO which follows one path to get to the content and will have to prepare study material individually. The intervention group will use the LSiLOs and will work with a partner to conform a study team. Students in this team will have different learning styles.

Table I. Students classification

\begin{tabular}{ccc}
\hline & Comparison & Intervention \\
\hline Activists & 5 & 3 \\
Reflectors & 2 & 5 \\
Theorists & 3 & 4 \\
Pragmatist & 5 & 3 \\
\hline Total & 15 & 15 \\
\hline & Source: Author
\end{tabular}

identified four types of learners (activists, reflectors, theorists, pragmatists). The LSQ measures a learner's preferred learning approach and the degree to which he or she is likely to learn.

With the application of the LSQ we managed to categorize the 30 students needed for the sample. The questionnaire was given without informing the students what would be done with it afterwards, but just asked for their cooperation for some statistics to be used in applying learning. Students showed interest in the test. Table I shows student distribution according to their learning style.

Students' different systematic thinking and learning skills can be accepted as the factors whose effects cannot be controlled and the matter of concern for this study.

\subsection{Research tools}

Intervention Group material involved the design and creation of four LOs, one for each learning style: active, theorist, pragmatic and reflector. Every new LO responds to different needs, therefore how they address the topic of study is different.

According to Rodríguez [24], each LO in the UFPS will include the following elements: Contextualization, (introduction/ presentation, objectives, and methods), Topics (subtopics), Prior knowledge, Tasks, Recommended materials (videos and texts), Practical cases, Data sheets, and Bibliography.

Also, Rodriguez [24] defined a series of templates for building OVAs according to the learning style. These templates define colors, knowledge path and visual distribution of elements.

Thus the LOs that developed for Active style allows students to have the same level of visibility in all components, it offers the possibility of explorer by preference or ability. Additionally it is constructed using colors like yellow, orange and red. For Pragmatic style, the LOs developed especially emphasize practical composing of 40 questions was given to both groups. The sum of each answer allows us to identify learning styles. The questionnaire 
cases and recommended material as students of this style like to try and see if things work in practice. The colors are brown, red, yellow and green. For Reflective style, the LOs developed involved the presentation of information available so that students can reach their own conclusion. Students of this style are observers and give importance to data collection. The colors are pink, brown, violet and green. Finally, LOs developed for Theoretical style involved the presentation of information in a structured manner, starting with prior knowledge and continuing with recommended material, activities and case studies. Students of this style are very methodical. The colors used are blue and gray [24].

The LO used for the comparison group use Active content distribution style. This decision was taken because this style is uniform for presenting information. Moreover, the aim is not to compare a well organized LO against a poorly organized one, but understand the benefit from using the same $\mathrm{LO}$ for all or use different LOs according to the learning style of each student.

Each LO will include a knowledge path based on particular characteristics from each style [24]. For each and every knowledge path a proposal for designing distribution schemes in response to each one was raised to be used in the construction of LOs within UFPS. The active style knowledge path can be seen in Figure 1.

Knowledge Path: Active Style

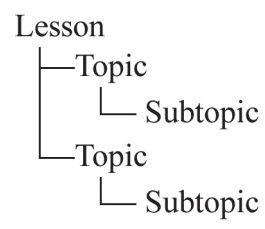

Prior Knowledge

Activities

Recommended Material

Practice Cases

Datasheet

Bibliography

Figure. 1. Knowledge path: active style Source: Author
To evaluate the effectiveness of our mixed strategy, two kinds of instruments were used. On one hand quantitative tools were designed in order to measure skill generation and knowledge appropriation. On the other hand, we developed qualitative assessment tools (Likert scale) to gain individual perception of how students interacted with the LO.

In designing assessments we reviewed information gathered by Logan and Thomas [9] who indicated, test content validity depends on carefully selecting items to be included. This is why the development of the assessment counted on the assistance of the two professors in charge of the course, who checked skills and wrote questions later discussing whether to include them in the final selection.

\subsection{Study}

In this study professor participation was reduced to avoid teaching skills becoming an uncontrollable variable. This study wasn't developed over the whole semester, it was done on a normal day and students were not warned about the class being given using LOs. The aim was to get to know students perception without prior knowledge of LO use.

Students were organized according to LS, intentionally mixing them to compliment one another's learning methods. The class was arranged into three stages. In the first, the professor explained how to use the LOs. Throughout this first stage, which lasted a total of 40 minutes, we encouraged students to really get to know the LO.

It must be mentioned that classes are held in rooms where each student has access to a desktop pc, allowing them to perform at their own pace in the learning process. This has been proven by Spektor-Levy and Granot-Gilat [10] in an research suggesting positive 1:1 computer initiatives, including increased student participation, decreased discipline problems and an increased use of computers for word processing, analysis and research. This initiative has shown significant
Julio-Diciembre 2014 ISSN 0122-820X

PP: 59-69 
No. 2

Julio-Diciembre 2014 ISSN 0122-820X

PP: 59-69 performance differences in favour of using computers in class.

Continuing with the study, the second stage was characterized by the checking of concepts learned. For this stage exercises similar to the examples given in the first stage were put into place with the objective of generating and reinforcing students programming skills.

Finally, in the third step, students from both groups were evaluated. In this stage both quantitative and qualitative tools were applied to students.

The quantitative assessment was composed of fifteen questions, each of them with four possible answers. The maximum score was five, and minimum zero. This assessment was done online in a controlled environment.

Additionally, a qualitative tool was applied to the students with the means of measuring the benefits of LOs from their own perspective. To do this we used the codification plan proposed by Kay [18] for the qualifying and receipt of student comments regarding LOs.

This plan assessed the LO from the perspective of learning interest and quality and consisted of 16 questions, each one being scored using a four point Likert scale (TAtotally agree, $\mathrm{A}$-agree, $\mathrm{D}$-disagree, $\mathrm{TD}$-totally disagree). This qualitative assessment was applied to students from both comparison and intervention groups.

\section{Results and analysis}

The average grade for students from the comparison group was 2.9 , with a minimum of 1.0 and a maximum of 4.0 . The intervention group did a little better with an average of 3.3, with a low of 2.0, and high of 4.3. Table II shows the results for group study and learning style.

Table II. Quantitative assessment results

\begin{tabular}{cccccc}
\hline & Activist & Reflector & Theorist & Pragmatist & Mean (SD) \\
\hline Comparison & 2.67 & 2.78 & 3.18 & 3.10 & $2.9(0.71)$ \\
Intervention & 2.73 & 3.42 & 3.40 & 3.53 & $3.3(0.64)$ \\
\hline
\end{tabular}

Source: Author

These results suggest the objective was met; effectively showing that providing content based LS and team-based leaning can improve a student's performance. Nonetheless, the result didn't generate the expected level of improvement. The intervention group grades were better than those of the comparison group though they should be analyzed further to get a more accurate conclusion applicable to our study context.

Looking at the qualitative test results, Table III shows us percentages of the answers given to some of our questions. These results were accompanied by comments assisting in enriching the $\mathrm{LO}$ design process.

Table III. Partial quantitative assessment results

\begin{tabular}{ccccc}
\hline Question & $T A$ & $A$ & $D$ & $T D$ \\
\hline Working with the learning object helped me learn & $33 \%$ & $35 \%$ & $21 \%$ & $11 \%$ \\
The learning object helped teach me a new concept & $46 \%$ & $49 \%$ & $5 \%$ & $0 \%$ \\
The learning object was easy to use & $11 \%$ & $23 \%$ & $50 \%$ & $16 \%$ \\
The learning object was well organized & $24 \%$ & $66 \%$ & $8 \%$ & $2 \%$ \\
I found the learning object motivating & $24 \%$ & $31 \%$ & $30 \%$ & $15 \%$ \\
\hline
\end{tabular}


Many students agreed that such learning tools help have a deeper understanding as well as developing their knowledge better, although content quality is fundamental. A lot of students favored the visual characteristics of the LO's, however, many felt they weren't challenging enough in motivating them to keep on learning. LO quality was seen well, together with a good use of colors and presentation.

The data analysis indicates that student performance improved thanks to LSiLOs and a strategy based on study teams. However, many students expressed they could have done better but were afraid to prepare the study subjects alone, this fear caused frustration and hence brought on a feeling of inability to learn.

This shows us that there are students who haven't the ability take the initiative of learning by themselves. Bringing us to the conclusion that these students have a low capacity for self-directed learning.

One thing expressed by comparison group students was the fact the LO was difficult to navigate and didn't show clear instructions of where to go next. And now from the professor's perspective, it is clear that the LOs currently employed are not particularly well designed, as there is no defined structure. Whereas LSiLOs are clearly organized and easy to handle at the time of reviewing activities. This has to be looked at in order to achieve a more accurate study.

Finally, another thing expressed by a few students was the fact they weren't sure how to answer the LSQ, what could have proposed a learning style not according to their learning nature. Also, a lot of students expressed they felt somehow distressed by the number of questions involved.

On the other hand, the strategy used to organize smaller study groups allowed them to discuss the required topics in a more informal, student-like, way. Being able to discuss such topics with fellow students was greatly favored as it gives them the chance to use their own expressions and build up knowledge in their own particular way. The LSiLOs activities included let them reinforce what they were learning. However, some groups showed difficulties in relating with each other given that each one had different LSs, in these cases the strongest student led the group with their own style.

Analyzing the results it's clear to see that even if the use of this mixed strategy doesn't considerably improve student performance, its use will help improve their learning. Regardless to say, it's important to clarify that the teaching strategies employed must be take into account.

Student comments also allow us to understand why they like using LOs or not. The students who enjoyed using them found them easy to use with good visual, graphical and other aids. They don't like them when they're challenging enough, when help is poor and full of too much text.

\section{Acknowledgements}

I would like to thank Professor Oscar Gallardo for their valuable support in early stages of this paper. I am also grateful to the Francisco de Paula Santander University, the Department of Systems and Informatics and to my students, without whom this research would not have been made possible. This paper is the result of the institutional project entitled "Creación de un Banco de Objetos Virtuales de Aprendizaje para los Cursos de Programación Orientada a Objetos I y II del Programa de Ingeniería de Sistemas de la UFPS".

\section{Conclusions}

This article describes a proposal to assess the effectiveness of learning styles in learning objects (LSiLO) and team-based learning. These LOs was designed according to learning styles described by Honey and Mumford [22] This study took place within the objectoriented programming course, for UFPS students.

The results obtained showed that if there is any improvement (except for Active group),
Julio-Diciembre 2014 ISSN 0122-820X

PP: 59-69 
No. 2

Julio-Diciembre 2014 ISSN 0122-820X

PP: 59-69 it isn't conclusive and should be followed up by semesterly evaluations. It's hard to say if the structure proposed for each style is what the students really need, or if rather just one LO could be developed with the student being able to navigate any way possible. Later studies will give us the chance to come to this conclusion.

We should identify why the results for Active learning style in the intervention group were lower than those in the comparison group. Some students had been hesitant to answer the LSQ, which may have caused to be identified to the wrong style. Similarly, we should review the LO's content to ensure that information was properly filed and organized.

Many students expressed fear of taking charge of their own learning. Self-directed learning can be seen as a somewhat radical change in the learning process. Also, students could review subject items in any order, without necessarily following the one suggested by the LS. This is a result of students in a rush to get as much knowledge as they can in as little time as possible. This could affect the results.

It could be a good approach think about Huang's [25] idea, which looks to apply LOs in the classroom, combining Professor's strategies with those prepared by students. Also, we are thinking about migrating LOs to social networks such as Facebook, giving students the chance to share results online creating a competitive culture between themselves.

We need to focus on creating appropriate content for each student to take advantage of the best way. It is important to make accurate and less dense surveys to identify appropriate learning style for each student, along with a more thorough review to ensure proper utilization of the study material content. It needs to be accompanied with semesterly systematic assessments to refine statistics such as those of the LOs.

This technology has the potential of being powerful enough to improve access to learning opportunities and a broader information society. With accurate design and planning we can take education to students everywhere, including the smallest towns and villages in the world [26].

\section{References}

[1] Francisco de Paula Santander University. School of System Engineering. Academic Curriculum. [Online]. Available at: http://ingsistemas.ufps.edu.co/index.php/ informacion-programa/pensum

[2] DANE, "Encuesta de Calidad de Vida 2012. Presentación De Resultados Región Central". [Online]. Available at: http:// www.dane.gov.co/files/investigaciones/ condiciones_vida/calidad_vida/ ECV_2012_RegionCentral.pdf

[3] A. Sánchez Jabba, "El bilingüismo en los bachilleres colombianos," Documentos de Trabajo sobre Economía Regional 009225, Banco De La República Economía Regional. 2012

[4] T. Jenkins, "The motivation of students of programming". Proceedings of the 6th annual conference on Innovation and technology in computer science education, Canterbury, United Kingdom. 2001.

[5] J. Villalobos, "Proyecto Cupi2 - Una Solución Integral al Problema de Enseñar y Aprender a Programar". Colombia Aprende. 2009

[6] E. Lahtinen, K. Ala-Mutka and $\mathrm{H}$. Jarvinen, "A study of the difficulties of novice programmers". Proceedings of the 10th annual SIGCSE conference on Innovation and technology in computer science education - ITiCSE '05. 2005

[7] J. Sajaniemi, P. Byckling, and P. Gerdt, "Animation Metaphors for ObjectOriented Concepts", Electronic Notes in Theoretical Computer Science, vol. 178, pp. 15-22, 2007

[8] J. A. Villalobos, N. A. Calderon, and C. H. Jimenez, "Developing programming skills 
by using interactive learning objects", ACM SIGCSE Bulletin, vol. 41, no. 3, p. 151, 2009.

[9] K. Logan, P.G. Thomas, "Learning styles in distance education students learning to program." 14th Workshop of the Psychology of Programming Interest Group, Brunel University, June. 2002.

[10] O. Spektor-Levy and Y. Granot-Gilat, "The Impact of Learning with Laptops in 1:1 Classes on the Development of Learning Skills and Information Literacy among Middle School Students". Interdisciplinary Journal of E-Learning and Learning Objects. vol. 8, pp. 83-96, 2012.

[11] Ü. Çakiroğlu, B. Adnan, and Y. Akkan, Yaşar, "The Effects of Using Learning Objects in Two Different Settings". TOJET, vol. 11, no. 1, 2012.

[12] D. A. Wiley, "Connecting learning objects to instructional design theory: A definition, a metaphor, and a taxonomy". Wiley, D.A. (Ed.), The Instructional Use of Learning Objects: [Online]. Available at: http://reusability.org/read/chapters/ wiley.doc

[13] P. Polsani, "Use and Abuse of Reusable Learning Objects", Journal of Digital Information, vol. 3, no. 4, feb 2006.

[14] N. Pukkhem and W. Vatanawood, "Personalised learning object based on multi-agent model and learners' learning styles". Maejo International Journal of Science and Technology, 2011.

[15] V. Adamchik, and A. Gunawardena, "A learning objects approach to teaching programming," Information Technology: Coding and Computing [Computers and Communications], 2003. Proceedings. ITCC 2003. International Conference on, pp.96,99, 28-30 April 2003.

[16] S. Conceição and R. Lehman, "An evaluation of the use of learning objects as an instructional aid in teaching adults". Midwest Research to Practice Conference in Adult, Continuing, and
Community Education, pp. 44-49. 2003.

[17] G. E. Kaiser. Constructing learning objects, 2002.

[18] R. H. Kay, "Examination of the Impact of Learning Objects in Secondary School", Journal of Computer Assisted Learning, vol. 24, pp. 447-461, 2008.

[19] S. Ruey-Shiang, "A study of the relationships among learning styles, participation types, and performance in programming language learning supported by online forums", Computers Eु Education, vol. 58, no. 1, pp. 111-120, January, 2012.

[20] J. W. Keefe, "Learning style: an overview". 1979.

[21] S. A. Griggs, "Learning styles counseling". Ann Arbor: ERIC Clearinghouse on Counseling and Personnel Services, University of Michigan, 1991.

[22] P. Honey and A. Mumford, "Using your learning styles", 1995.

[23] D. Kolb, "Learning style inventory technical manual". 1976.

[24] P. Rodriguez, "Implementación de una estrategia de divulgación del conocimiento generado a partir de las líneas de investigación y de agentes educativos de la comunidad académica UFPS". Grupo de Investigación en Ingeniería de Software. 2011.

[25] E. Y. Huang, S. Wei Lin and T. K. Huang, "What type of learning style leads to online participation in the mixed-mode e-learning environment? A study of software usage instruction", Computers Eु Education, vol. 58, no. 1, pp. 338349,2012 .

[26] P. Kim, T. Hagashi, L. Carillo, I. Gonzales, T. Makany, B. Lee and A. Gàrate, "Socioeconomic strata, mobile technology, and education: a comparative analysis". Educational Technology Research and Development, vol. 59, pp. 465-486, 2011. 